\title{
Past and Present at Wonderwerk Cave (Northern Cape Province, South Africa)
}

\author{
Liora Kolska Horwitz ${ }^{1}$ - Michael Chazan ${ }^{2,3}$
}

Published online: 12 December 2015

(C) Springer Science+Business Media New York 2015

\section{Introduction}

The Northern Cape Province and neighboring North West Province (Bokone Bophirima) of South Africa provided the first scientific evidence for the centrality of Africa for hominin evolution. In the late 1800 s, long before the fossil hominin finds at Olduvai Gorge in East Africa or the Cradle of Humankind sites in Gauteng Province, alluvial diamond diggers found extensive assemblages of Earlier Stone Age (ESA) artefacts in the Vaal River gravels at localities such as Klipdrift (Canteen Kopje) in the Northern Cape (Johnson and Young 1906). World-famous prehistorians visited the area and described the archaeological findings (e.g., Péringuey 1911; Goodwin 1928; Goodwin and van Riet Lowe 1929; Breuil 1945; Mitchell 1998; Kunneriath and Gaillard 2010). Despite the extraordinary discovery of the Taung Australopithicine skull in 1924 at a quarry located $c a .120 \mathrm{~km}$ to the northeast of the Vaal gravel localities (Dart 1925), in the following years, this region was largely overlooked by the scientific community. This was due to the fact that the Taung skull had no clear archaeological context, while confusion sown by the "Piltdown Man" and resulting debates surrounding what constituted the "missing link" occupied primary place in discussions within the anthropological community (Tobias 1992). The spectacular fossil hominin finds in East Africa and Gauteng from the 1940s onwards further shifted the spotlight away from the Northern Cape, even though numerous paleontological and archaeological

Michael Chazan

mchazan@chass.utoronto.ca

Liora Kolska Horwitz

lix1000@gmail.com

1 National Natural History Collections, Faculty of Life Sciences, The Hebrew University, Jerusalem, Israel

2 The Archaeology Centre, Department of Anthropology, University of Toronto, Toronto, ON, Canada

3 Evolutionary Studies Institute, University of the Witswatersrand, Johannesburg, South Africa 
investigations of the Pleistocene and Pliocene continued in this region (e.g., Malan and Cooke 1941; Camp 1948; Peabody 1954; Power 1955; Wells 1964; Sampson 1974; Butzer et al. 1978).

Wonderwerk Cave $\left(27^{\circ} 50^{\prime} 44.7^{\prime \prime} \mathrm{S}, 023^{\circ} 33^{\prime} 12.3^{\prime \prime} \mathrm{E}\right)$, situated at the base of a low foothill on the eastern flank of the Kuruman Hills on the farm "Wonderwerk" (Fig. 1), is among the most impressive archaeological sites in the Northern Cape Province. The cave is an enormous dolomitic cavity (Fig. 2, ca. $140 \mathrm{~m}$ long, 3-7 m high, 11-26 m wide) that has yielded archaeological deposits with Earlier, Middle, and Later Stone Age remains (ESA, MSA, LSA, respectively), spanning the past ca. 2.0 Ma years (Humphreys and Thackeray 1983; Beaumont and Vogel 2006; Matmon et al. 2012; Chazan and Horwitz 2015). The lengthy cultural sequence preserved at Wonderwerk has provided suitable contexts for dating, and the good preservation of faunal and botanical remains which offer excellent proxies for paleoenvironmental studies, making this site an archaeological and paleontological locality of global significance for studying human evolution.

The location of Wonderwerk in the semiarid interior of South Africa-a region whose archaeology is not well known, especially for the ESA - adds to the importance of this unique cave. Today, Wonderwerk Cave lies in a summer rainfall area, with a mean annual precipitation of $c a .480 \mathrm{~mm}$ (South Africa Rain Atlas), characterized by hot summers and dry, cold winters with regular frost. The regional vegetation is classified as belonging to the Savanna Biome, though a mosaic of local vegetation groups are found in the environs of the cave (Mucina and Rutherford 2006; Bamford 2015b, this issue; Brink et al. 2015, this issue; Scott and Thackeray 2015, this issue). To the west and south of the cave, the Savanna Biome grades into the Nama Karoo, while to the east it trends into the Grassland biome (Fig. 3).

Wonderwerk is located along the route that led from the Vaal River to the Moffat Mission in Kuruman, and it is likely that the site was visited frequently by early travelers in the region. As shown in Fig. 1, a cave that likely corresponds to Wonderwerk is indicated on a map published in 1844. This map shows clearly that, in the years preceding the diamond rush, the Kuruman Hills were relatively well travelled primarily due to the presence of the Moffat Mission. The cave is described in publications of European travelers, for example, James Backhouse (1844), who visited the region in 1839 but did not visit the cave himself, and Methuen (1846), who did enter the cave in 1844 .

Between 1909 and 1911, the cave was inhabited by the farm owners, the Bosman family, who initially lived in the cave while their farmhouse was being built and subsequently used the cave as a cart-house and winter sheep shelter until the early 1930s. A newspaper article from 1937 documented a visit to Wonderwerk Cave by E.E. Buttner, a water inspector, who remarked on the immense size of the cave, the presence of a thick layer of bat guano on the cave floor, and the presence of "some Bushman flint axes" which he recovered from a hole, several feet deep, that he dug into the cave floor. He presciently noted "Systematic excavation might yet bring some very interesting relics of past civilisations to light" (Buttner 1937). During the Second World War, the organic deposits of the cave (from $c a .30 \mathrm{~m}$ in from the cave entrance to the back of the cave) were exploited commercially by the farmer's family. A collection of unprovenanced fossil bone and lithic artifacts recovered from the guano diggers' pits 

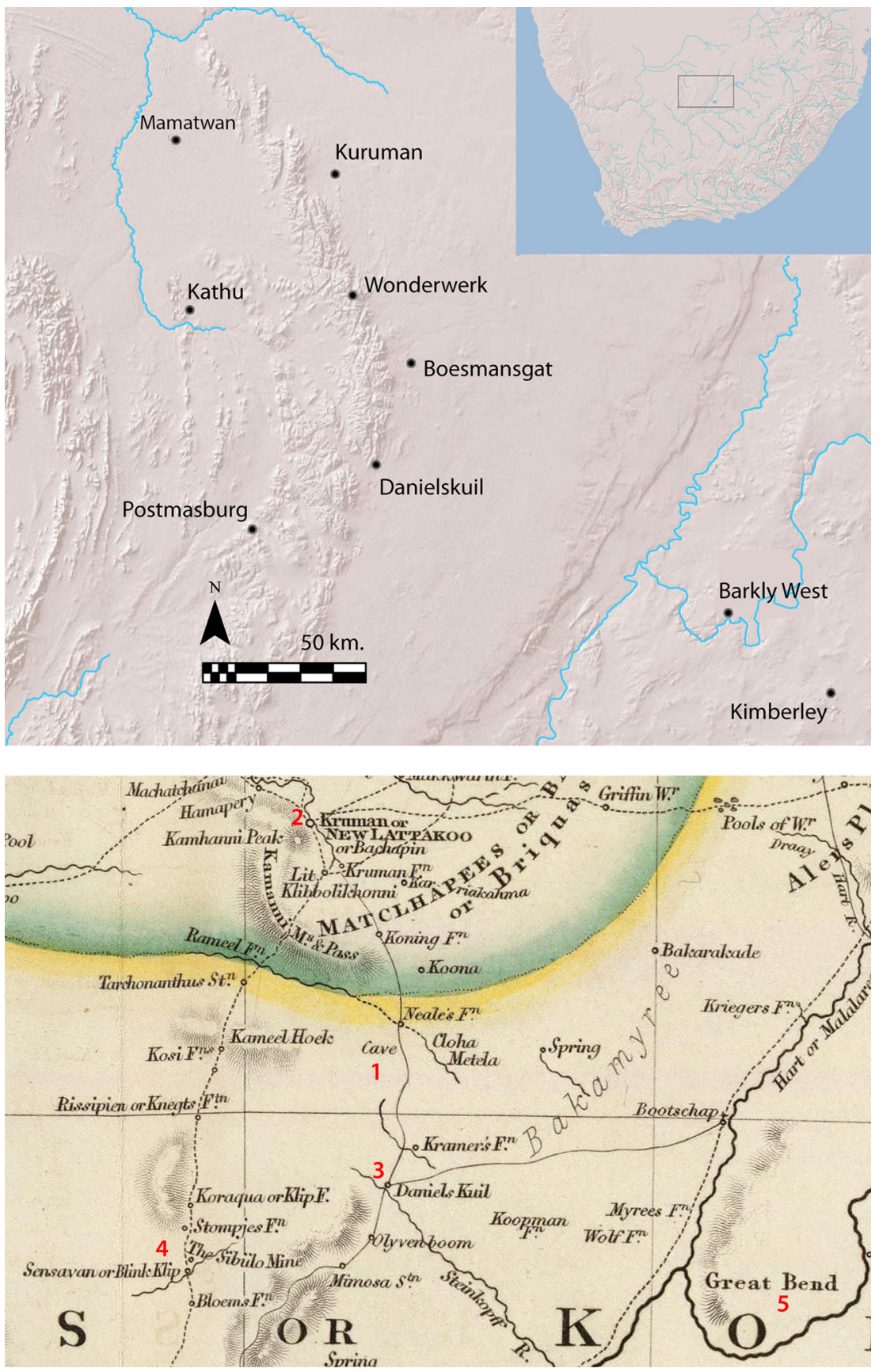

Fig. 1 Top: Map showing the location of Wonderwerk Cave and other sites mentioned in the text. Bottom: Detail of map of South Africa published in 1842 (Cape of Good Hope, published in The London Atlas of Universal Geography, J. Arrowsmith. London copied from the Original M.S. drawing in the Colonial Office, compiled by Mr. Hebert Senr.; used under terms of Creative Commons license, Cartography Associates). Annotations by us show: 1 cave corresponding to the location of Wonderwerk Cave, 2 Kuruman, 3 Danielskuil, 4 Blinkklip specularite mine (Postmasburg), 5 Barkly West (image in full color online) 


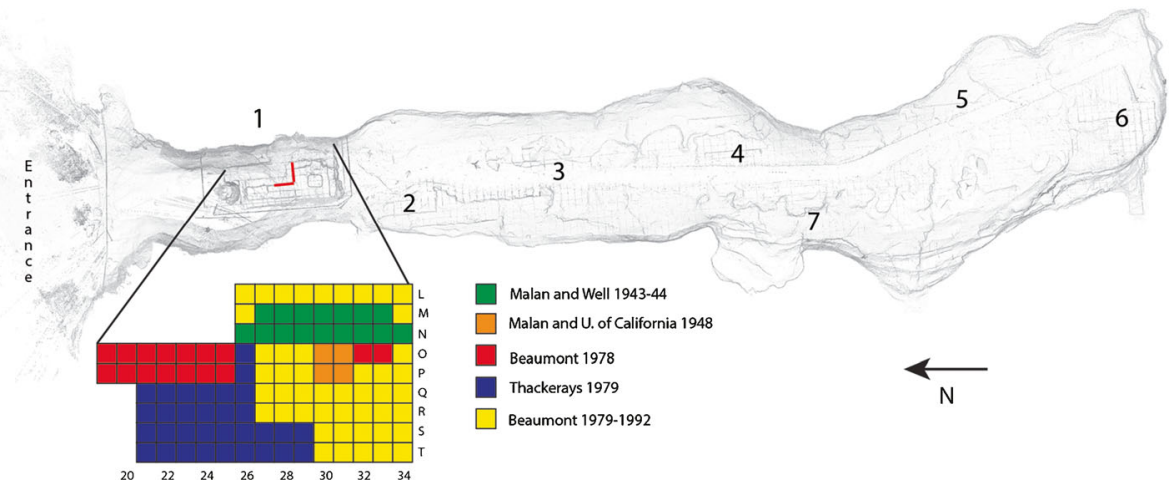

Fig. 2 Plan of Wonderwerk Cave with the seven excavation areas indicated. Detail shows the excavation history of excavation 1. Red line indicates profiles where dating and geological samples were collected. Cave plan courtesy of Heinz Rüther and the Zamani Project (University of Cape Town) (image in full color online)

was sent to the Bureau of Archaeology in Johannesburg in the early 1940. These finds spurred interest in the cave, resulting in two seasons of excavation (1943 and 1944) near the front of the cave led by the archaeologist B.D. Malan (Figs. 2 and 4; Malan and Wells 1943). This was followed by a short excavation season in 1945, a collaboration between Malan and the University of California African Expedition southern section (Camp 1948). This research established that the site contained artifacts and faunal remains dating to the Earlier, Middle, and Later Stone Ages. Then, in 1974 and 1977, a study of the sedimentology and geochemistry of the standing sections was undertaken by K.W. Butzer (Butzer et al. 1979; Butzer 1984a, b). Between 1978 and 1996, seven excavation areas in the cave were excavated by P.B. Beaumont, then archaeologist at the McGregor Museum, Kimberly (Figs. 2 and 5; Beaumont 1982, 1990, 2004; Beaumont and Vogel 2006). In excavation 1, the deepest sounding in the cave (ca. $6 \mathrm{~m}$ deep), Beaumont reported the presence of deposits containing ESA artifacts in seven archaeological layers (strata 12 to 6), overlain by four layers containing LSA material (strata 1-4) while the intermediate stratum 5 contained both LSA and ESA remains. For the 1979 season, Beaumont was joined by F.J. and A. Thackeray who excavated the LSA layers in excavation 1 (Thackeray et al. 1981; Humphreys and Thackeray 1983; Thackeray 1983, 1984). Though several publications have described research findings from the Beaumont and Thackeray excavations (e.g., Beaumont 1982, 1990, 2004; Humphreys and Thackeray 1983; Thackeray 1983, 1984, 1988; Binneman and Beaumont 1992; Avery 1995; Thackeray and Lee-Thorp 1992; Beaumont and Vogel 2006), including documentation of some of the oldest art mobilier in southern Africa dating to ca. 10,000 years BP (Thackeray et al. 1981; Bradfield et al. 2014), a significant portion of the material that had been collected, especially from the ESA and MSA deposits, was not examined or published.

In 2004, an interdisciplinary project, directed by the authors, was initiated. There were several aims:

(i) Studying the excavated and as yet unstudied finds (lithic, faunal and botanical) from the Beaumont and Thackeray excavations;

(ii) Contextualizing these finds in terms of their geological and chronological settings; 


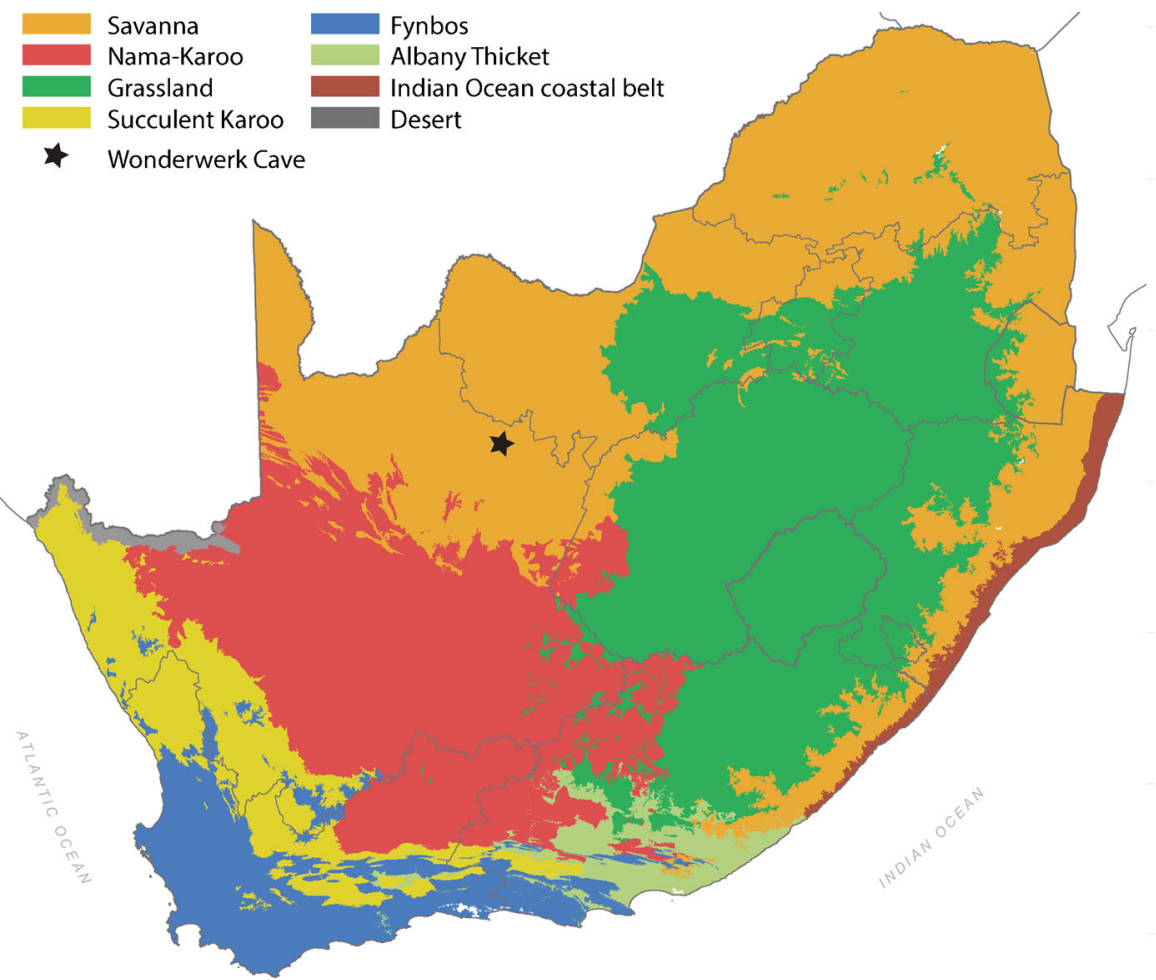

Fig. 3 Modern biomes of South Africa with the location of Wonderwerk Cave indicated (after Rutherford et al. 2006: Fig. 3.2) (image in full color online)

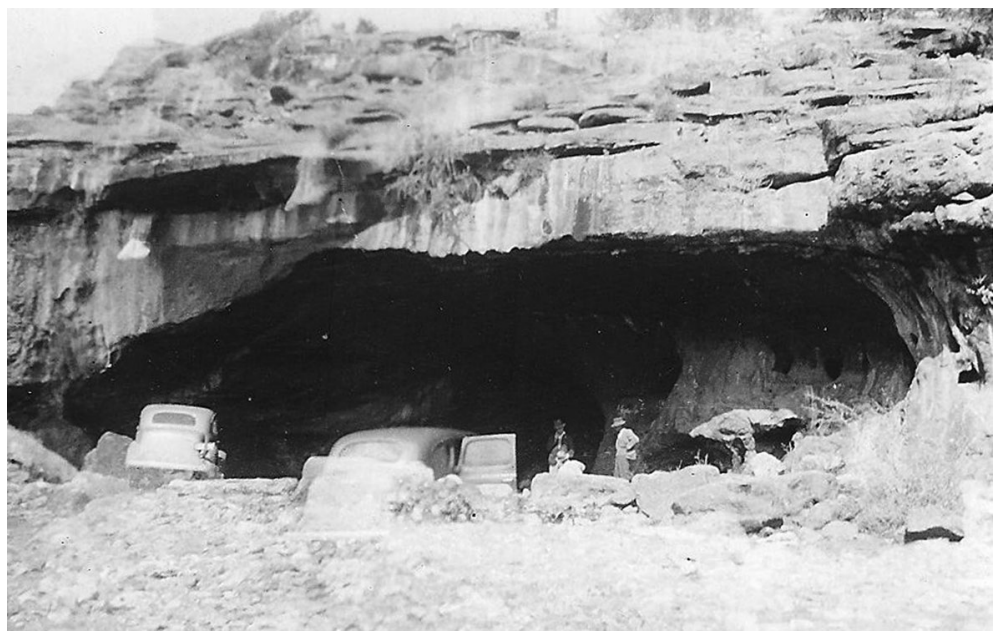

Fig. 4 Photograph of the Malan expedition at Wonderwerk Cave (from the Malan archives, University of Witwatersrand) 


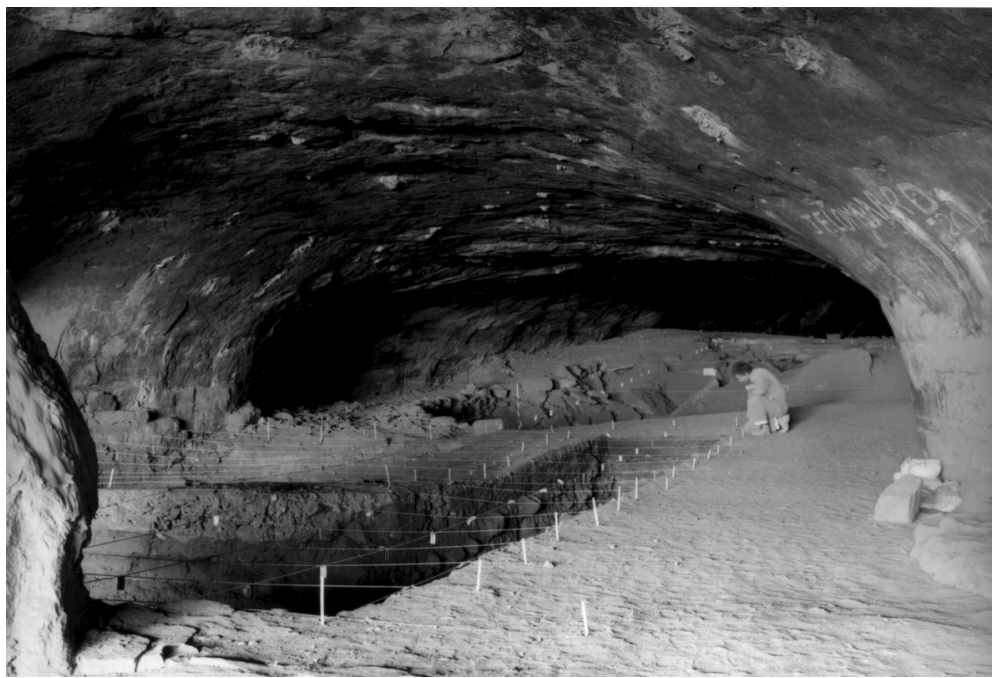

Fig. 5 Photograph of Peter Beaumont during excavation in the 1970s at Wonderwerk Cave. The stalagmite is visible on the left side of the image. The view is towards the cave interior (courtesy of the McGregor Museum, Kimberley)

(iii) Examining the association of the different finds within and between strata;

(iv) Directly dating the ESA levels using a range of chronometric methods as well as filling gaps in the Holocene dating sequence;

(v) Reconstructing the palaeoenvironmental and palaeoclimatic conditions that prevailed around the site and in the region as a whole over the entire chronological sequence;

(vi) Undertaking fine resolution excavation to clarify stratigraphic associations and the nature of the cave occupations, and

(vii) Publishing all finds from past excavations in the cave as well as from current ones.

Recognition of the archaeological significance of Wonderwerk Cave has been a gradual process. To date, several papers resulting from this new project have been published (e.g., Avery 2007; Brook et al. 2010; Berna et al. 2012; Chazan and Horwitz 2009, 2015; Chazan et al. 2008, 2012; Matmon et al. 2012; Brink et al. 2015; see project website http:/www.wonderwerkcave.com), and numerous papers and posters presented at international conferences. A particularly significant milestone was the creation of a 3D model of the cave by the Zamani Project (Rüther et al. 2009). The ten papers in this special issue of African Archaeological Review, along with three forthcoming papers to be published in a subsequent issue of this journal in 2016, provide a further and especially valuable contribution, since they afford the first in-depth overview of central aspects of this important archaeological locality. The papers focus on Pleistocene and Holocene material from the front of the cave, primarily from Excavation 1, located immediately behind a large stalagmite situated ca. $20 \mathrm{~m}$ in from the cave entrance (Fig. 2).

\section{Stratigraphy and Dating}

Peter Beaumont collaborated with J.C. Vogel to develop a radiocarbon chronology for the LSA levels at Wonderwerk, and both A. and F.J. Thackeray pursued similar 
analytical work (for a summary of all their 14C dates, see Lee-Thorp and Ecker 2015, this issue; Scott and Thackeray 2015, this issue). Though the quantity and caliber of the $14 \mathrm{C}$ dates were excellent, they were never calibrated or modeled to create a robust chronostratigraphic framework. This work has now been undertaken by Scott and Thackeray, as well as Lee-Thorp and Ecker, and is presented in this issue. The calibrated 14C series using Bayesian models provides new insights into the LSA chronology: (i) four previously unpublished dates were added, (ii) the calibration and modeling produced a longer sequence than previously reported based on radiocarbon years alone and now spans some 15,000 years, and (iii) the model provides greater accuracy for the timespan of the occupation of each stratum. This new analysis provides an excellent basis for understanding the extensive Holocene sequence in Excavation 1.

The Earlier Stone Age archaeology in southern Africa has long been limited by the absence of reliable dating methods. Beaumont and Vogel (2006) employed U/Th dating of speleothems to extend the chronology of the cave into the Pleistocene and also reported the findings of the paleomagnetic analysis undertaken by K. L. Verosub of Excavation 1 (Beaumont and Vogel 2006: Tables 2 and 3). Unfortunately, these results are incompletely presented and so of limited value in providing a comprehensive chronological framework for the ESA in Excavation 1.

Developing a robust chronometric framework for the Earlier Stone Age deposits at Wonderwerk was one of the key goals of our renewed research project. The principles underlying this research have been the application of multiple methods, and the importance of understanding the geological contexts of the samples used for dating. Dating specialists are involved in fieldwork and take samples themselves whenever possible.

For the ESA, the most productive methodology for Wonderwerk Cave has been the pairing of paleomagnetism and cosmogenic burial age dating, which are independent systems that both rely on a thorough understanding of geomorphology. The paper in this issue by Goldberg et al. provides the critical geological context for the dating program based on a combination of field observations, micromorphology, and FTIR analysis. At a broader scale, Matmon et al. (2012) provide grain size analysis that demonstrates that the Kalahari was the primary source for the sands found in the Wonderwerk infill.

Paleomagnetic dating determines the direction of the earth's magnetic field when sediments were deposited. A paleomagnetic sequence can be correlated with the global magnetic sequence; however, it is essential that there is an anchor that places the signal in the global curve. In Wonderwerk Excavation 1, the paleomagnetic analyses have identified a sequence of Normal $>$ Reverse $>$ Normal (Chazan et al. 2008; Matmon et al. 2012). To anchor this sequence, we turned to cosmogenic burial age dating (Matmon et al. 2012). This method determines the time that has elapsed since sediment has been shielded from cosmogenic radiation using the ratio of cosmogenic isotopes ${ }^{26} \mathrm{Al} /{ }^{10} \mathrm{Be}$, which have different decay rates. The burial history of sediments prior to their entry into the cave complicates the interpretation of isotope ratios and it is important to keep in mind that the results obtained tell us when the sediments first entered the cave rather than the timing of their final deposition.

The extensive cosmogenic sequence in Excavation 1 permits us not only to anchor the paleomagnetic sequence, but in some cases to also further constrain the age of 
deposits. The lower normal (in stratum 12) is bracketed by ages that situate it in the Olduvai event, while the upper normal (strata 10 and 9) is bracketed by cosmogenic burial age dating consistent with the Jaramillo subchron, a brief event of only $100 \mathrm{kyr}$. It is important to emphasize that the paleomagnetic and cosmogenic ages are in complete agreement on the age of this sequence. Unfortunately, the intervening reversal (top of stratum 12, stratum 11, and bottom of stratum 10) is a very long period and further cosmogenic age determinations are needed to further constrain the age of deposition within this time period. The uppermost part of the ESA sequence (strata 8-6) is not yet constrained by cosmogenic burial ages, and for the upper part of stratum 9, only paleomagnetic dating is available. All of stratum 9 was deposited during conditions of normal polarity. However, for the upper part of the stratum, where we currently lack cosmogenic ages, we cannot rule out the possibility that it was deposited during the Jaramillo subchron and not the Bruhnes chron. If this scenario is correct, this would require the presence of a major unconformity within Stratum 9.

Dating ESA deposits at Wonderwerk Cave using OSL (including TT-OSL) have been unsuccessful (Chazan et al. 2008; Naomi Porat, pers. comm.), but this method will doubtless be of great value for dating the MSA and even LSA strata. Pickering (2015, this issue) describes $\mathrm{U} / \mathrm{Pb}$ dating of small speleothem straws that have produced meaningful results. However, the significance of these results for Wonderwerk Cave are limited, to some extent, by the imprecise nature of provenance data for material from Beaumont's excavation (for details on provenance problems, see papers in this issue by Chazan, and Birkenfeld et al.). U/Pb dating will, however, have potential to make a major contribution in the context of the renewed excavations.

The current project has, as yet, not undertaken extensive dating of the other excavation areas within the cave. One exception is Excavation 6 at the back of the cave for which both the paleomagnetic and cosmogenic burial dating sequences have been published (Matmon et al. 2012). Work is currently underway to date the sequence in Excavation 2 (e.g., Pickering 2015, this issue), which includes an MSA component.

\section{Material Culture}

Pleistocene archaeological deposits are found in three areas of the cave (Fig. 2): Excavation 1 (front of cave behind a large stalagmite), Excavation 2 (behind and offset immediately to the right of Excavation 1), and Excavation 6 (located in the very back of the cave, $140 \mathrm{~m}$ in from the entrance). Excavation 6 has produced a remarkable assemblage attributed to the Fauresmith associated with quartz crystals, modified ochre, and specularite (Chazan and Horwitz 2009; Chazan 2015a; Watts et al. 2015). In Excavation 2, a sequence that includes ESA and MSA components was documented (Beaumont and Vogel 2006). The detailed analysis of these collections is still in process, but the attribution of stratum 2 in Excavation 2 to the MSA, as proposed by Beaumont, is secure.

In Excavation 1, the ESA sequence (strata 12 through 6) is truncated by stratum 5 and is immediately overlain by four LSA strata (strata 4 through 1), subdivided in places into sub-units (a-d). The LSA lithic sequence has previously been described by A. Thackeray (Humphreys and Thackeray 1983). It comprises an Oakhurst industry, locally designated as the Kuruman Industry, in stratum 4d (with a boundary age of 
12,900-9,000 cal. BP; Lee-Thorp and Ecker 2015, this issue) dominated by scrapers, with banded ironstone and dolomite used as raw materials. It is overlain by a Wilton industry (in strata 4b-c) characterized by scrapers on banded ironstone $(5,500-9,800 \mathrm{cal}$ BP). A marked shift in artefact types and raw material is evident at the top of level $4 \mathrm{~b}$. The overlying Wilton industry, in strata $4 \mathrm{a}$ to $3 \mathrm{~b}$, contains backed bladelets on chert $(5,800-2,300$ cal. BP) finally topped by a ceramic LSA in strata $2 b-3 a(900-2,800$ cal $\mathrm{BP})$ and historic period material (disturbed contexts) in strata 1-2. The nature of stratum 5, which is characterized by subrounded dolomite clasts and both ESA and LSA lithic material, is the subject of ongoing investigation (e.g., Bamford 2015a, b, this issue; Lee-Thorp and Ecker 2015, this issue; Scott and Thackeray 2015, this issue).

The rock art adorning the first $40 \mathrm{~m}$ of the cave walls is a rare example of painting in a region where rock engravings, but not paintings, are widespread. The rock art includes a wide diversity, both thematically and stylistically, of animals and geometric forms. In a forthcoming article, Morris (2015) presents the first extensive discussion of this important corpus. One of the great challenges for site management at Wonderwerk is providing for the long-term preservation of the paintings while allowing for visitor access. A graffiti-removal project undertaken in 1993 by S. Bassett and J. Deacon was intended to provide a remedy for the extensive historical graffiti that largely obscured the cave paintings. Unfortunately, this intervention, which included infilling and overpainting, has not weathered well, leading to additional conservation challenges. Wonderwerk is also well known for the decorated stone slabs recovered during excavation in the LSA strata, which were the earliest securely dated art in Africa long before the dramatic discoveries at Blombos Cave (Thackeray et al. 1981; Beaumont and Vogel 1989). Thackeray and colleagues (Thackeray 2005; Bradfield et al. 2014) have recently returned to the interpretation of the images found on these slabs.

The ESA of Excavation 1 provides a unique opportunity to track the development of Acheulean lithic technology over time. It is important to emphasize that the Oldowan/ ESA lithics in Excavation 1 occur in low densities. The paper by Chazan in this issue provides the first extensive technological analysis of this assemblage. The timing and nature of technological changes in the Acheulean at Wonderwerk fit well with what is known in East Africa, despite limitations in chronological resolution for the early stages at Wonderwerk Cave.

An important discovery resulting from the renewed investigations at the site has been the presence of an Oldowan industry in stratum 12, at the base of Excavation 1, that is characterized by small tools including flakes and cores. The absence of large choppers, cleavers, and spheroids in the Wonderwerk Oldowan might be a result of the small sample size. The presence of a small flake component fits well with what is known of the Oldowan from the South African sites of Sterkfontein and Swartkrans (Granger et al. 2015) and several East African sites (see discussion and references in Chazan et al. 2012). The cultural attribution of this industry at Wonderwerk is supported both by the chronometric ages for this layer and the biochronology of the macrofauna, which contains archaic elements including two extinct species of hyrax (Procavia), and an extinct large caprine (Brink et al. 2015, forthcoming). Thus, the faunal taxa associated with the Wonderwerk Oldowan assemblage share common features with other sites dating to the Makapanian Land Mammal stage, such as Makapan Limeworks Member 3 (Reed 1996), Swartkrans Members 1 and 2 (De Ruiter 2003; Watson 2004), and Sterkfontein Member 5 (Ogola 2009). 
The in situ nature of the Oldowan deposit has been demonstrated by the micromorphological analysis of the sediments, further supported by the distance of the excavated material from the current cave mouth and absence of alternative entrances. These findings make the stratum 12 deposit at Wonderwerk the earliest evidence for intentional cave occupation worldwide (Chazan et al. 2012; Goldberg et al. 2015, this issue).

During his excavations, Beaumont recorded provenience of finds in $10 \mathrm{~cm}$ spits within 1 yard-square units. Consequently, there are limits to the precision of the spatial data from his excavations, and the absence of detailed field notes and photographs makes correlation between archaeological strata and depositional events even more problematic. However, the spatial data available do allow exploration of association between classes of material recovered and the spatial organization of activity within strata. To overcome this drawback, Birkenfeld et al. (2015, this issue) have used GIS to create virtual reconstructions of spatial and temporal distributions of finds from excavation 1, despite the absence of piece-plotted data. The virtual excavation grid they created acts like a cupboard, in whose drawers (excavated squares) the different finds are placed in virtual space based on their square number, stratum attribution, and depth data. The authors were able to test both the vertical and horizontal dispersal of macroand microfaunal remains from the Oldowan/ESA levels. This innovative study holds great promise for analysis of patterning in the "old collections" from the cave, while given that all finds from the new excavation are geo-referenced, results of spatial analyses based on the old assemblages can be verified in the future.

\section{Evidence for Use of Fire}

Based on macroscopic observations, Beaumont (2011) identified potential evidence for the use of fire at Wonderwerk as far back as stratum 12. In a publication from the following year, Berna et al. (2012) provided the earliest, well-contextualized evidence for the use of fire by hominins $c a$. 1.0 Ma years ago, based on the identification of wood ash in micromorphology slides from stratum 10 in Excavation 1, dated to the Jaramillo subchron. This initial observation is supported by FTIR analysis of bones from this layer that show evidence of burning and potlid fractures on lithic material. Potlid fractures have now been observed on artifacts recovered in situ in the renewed excavations of stratum 10, providing corroboration for this finding.

Several papers in this issue bring new perspectives to our understanding of the use of fire at Wonderwerk. Goldberg et al. (2015, this issue) examine the evidence for fire in stratum 10 and point to the need for caution when identifying ash in micromorphological slides from this layer, given the co-occurrence of rhizoliths that have a similar morphology to burnt ash. Chazan et al. (2012) have presented evidence for burnt micro- and macrofauna in the Oldowan assemblage from stratum 10, while the current papers by Fernandez-Jalvo and Avery (2015, this issue) and Brink et al. (forthcoming) provide further evidence for burnt fauna and microfauna in the underlying strata 11 and 12. Fernandez-Jalvo and Avery (2015, this issue) report a high proportion of micromammalian remains with evidence of burning, including calcined bones. Moreover, the burnt bones appeared to be in concentrations. The authors note that both traits do not fit with natural fires. According to Brink et al., the fact that a large proportion of the macromammalian remains in these layers was burnt may have 
contributed to the extensive fragmentation to both bones and teeth in this assemblage. Bamford (2015b, this issue) reported one piece of charcoal from stratum 12, while no large charcoal fragments were recovered from stratum 10 (Berna et al. 2012). Calcified roots and plant litter from stratum 10 were tentatively interpreted as kindling (Berna et al. 2012). The caliber of the observations for intentional use of fire in stratum 12, then, differs from that available from stratum 10 where burnt material could be identified in context on preserved surfaces through the use of micromorphology. It is unlikely that such a level of resolution will be found for stratum 12, as the sediments that compose these strata were deposited by low energy, sheet-water flow and as such do not preserve intact surfaces. Thus, the nature and significance of the evidence for fire in the Oldowan of Wonderwerk Cave require further investigation, though it seems beyond question that fire (intentionally or accidentally) was present in the cave as early as the Oldowan occupation, at least 1.5 Ma years ago.

\section{Palaeoenvironmental and Palaeoclimatic Evidence}

One of the major contributions that renewed research at Wonderwerk Cave can make to the archaeological record of southern Africa lies in the study of past environments and climatic conditions. This stems from the dearth of suitable datasets from the interior of southern Africa that can serve as climatic proxies. The excellent preservation of organic remains at the cave, the presence of a robust chronometric framework, and the association with a long cultural record makes this a rare archive.

\section{Late Pleistocene and Holocene}

Five papers in this special issue have provided invaluable information on the Late Pleistocene and Holocene aspect of Wonderwerk Cave. They extend several published research papers on the palaeoecology and palaeoclimatology of the cave and provide relevant new insights. Using a combination of radiocarbon dating, isotope ratios, histology, and palynology, in this issue, Brook et al. examined two tufas and reexamined the sequence of a core from the large stalagmite adjacent to Excavation 1 that they had previously published (Brook et al. 2010). Scott and Thackeray reexamined the palynological sequence from strata 1 to 5 in Excavation 1, building on the work of van Zinderen Bakker (1982) and Scott et al. (1995), and link it with the palynological results of Brook et al. (2010). Thackeray presents results of his analysis of the Holocene fauna that expand previous studies on macromammals (Thackeray 1983, 1984, 1988; Thackeray and Brink 2004) and micromammals (Avery 1981, 1995). Lee-Thorp and Ecker analyzed ostrich eggshell (OES) fragments for carbon and oxygen isotope ratios for the entire Holocene sequence that extend stable isotope results, such as the ratios of equid teeth (Thackeray and Lee-Thorp 1992) and the large stalagmite adjacent to Excavation 1 (Brook et al. 2010), while Bamford reports on new palaeobotanical finds from the Late Pleistocene (stratum 5), in addition to the scanty ESA macrobotanical remains. Finding concordance in these data sets has facilitated the identification of a succession of changes in environmental conditions and vegetation composition (Fig. 6). Given the brevity of this introduction, only the most general trends are presented. It should be noted that there are some conflicting results and 


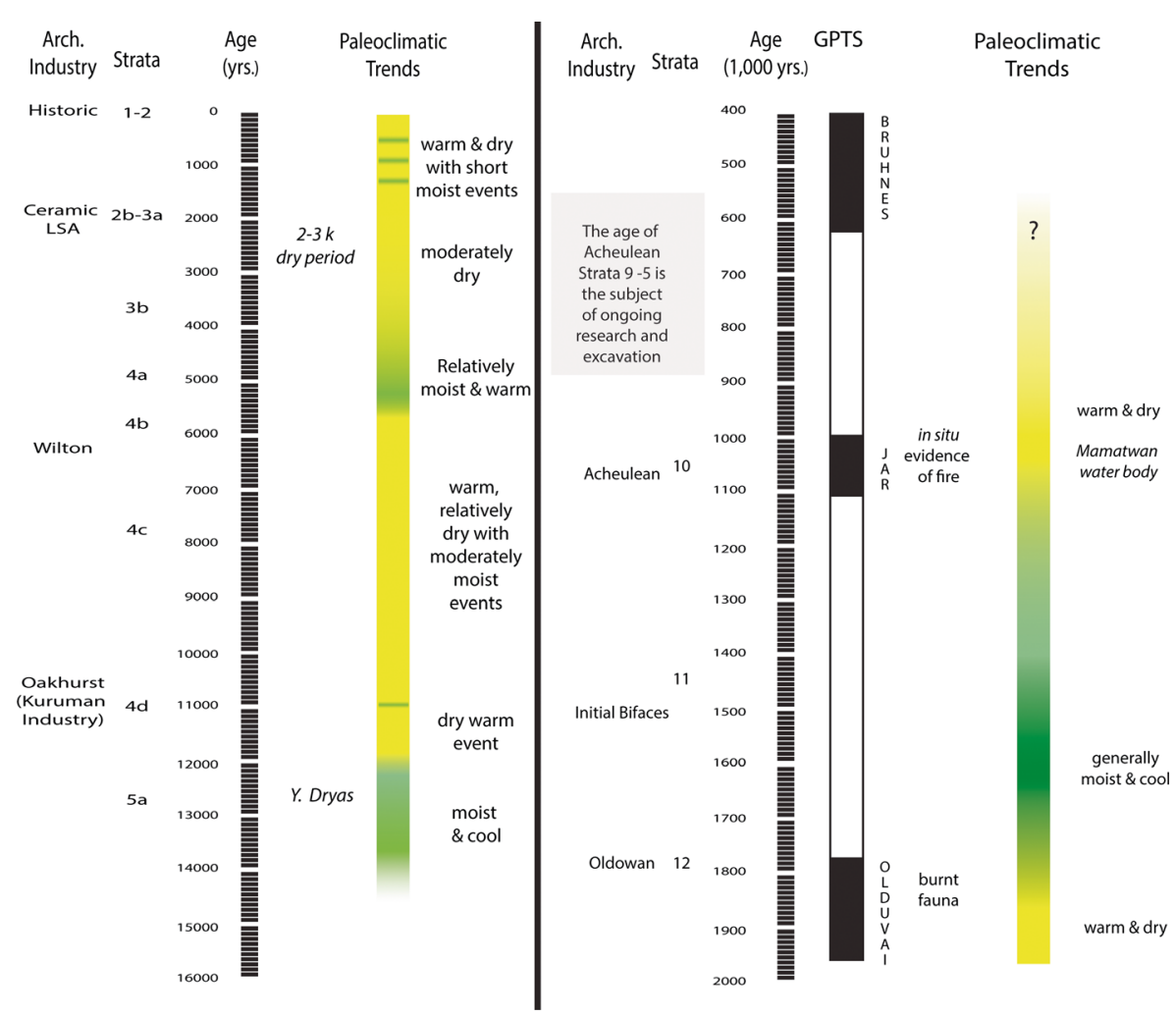

Fig. 6 Schematic synthesis of the main palaeoclimatic trends and the archaeological sequence at Wonderwerk Cave, Excavation 1

chronological disjunctures in episodes rather than overall palaeoenvironmental/climatic trends. These may be the result of differences in the sensitivity of the different proxies to change, the nature of the environmental/climatic data that the sampled material actually reflects, and differences in the accuracy of chronological resolution due to varied sampling methods. The ostrich eggshell, macrofauna, and macrobotanical samples derive from the Beaumont excavations and were dated using their overall attribution to archaeological strata, while the pollen samples reported here were collected more recently from freshly cleaned sections, and attributed to strata based on observed stratigraphy visible in the section that were dated previously by radiocarbon from charcoal or ostrich eggshell. Finally, the tufa and stalagmite cores were sampled with great refinement in a laboratory (see papers in this issue for details).

The contribution here by Brook et al. supplies the first dates for tufa deposits located immediately outside and just inside the current cave entrance. All are younger than $c a$. 3000 cal year BP, providing an important corroboration that in the past they formed under more protected conditions, when the cave entrance was located further forward, but subsequently receded since the early Pleistocene as initially proposed by Matmon et al. (2012).

Examination of a core extracted from the stalagmite adjacent to Excavation 1 provided information on moisture penetration into the cave and hence palaeoclimatic conditions in the region (Brook et al. 2010). Evidence for growth of the speleothem 
implies that conditions were moist enough for water to penetrate the epikarst, while a hiatus represents periods when this did not happen, presumably because there was not enough moisture penetration. Based on this core, moist and cool conditions were reported for the Late Pleistocene at $c a$. 35,000-33,000 cal year BP and $c a$. 22,00014,000 cal year BP with brief, dry episodes at $c a$. 34,000 cal year BP, $c a$. 22, 000 cal year $\mathrm{BP}$, and ca. 15,000 cal year BP (Brook et al. 2010). Pollen recovered from inside this stalagmite core also provides palaeoclimatic indications. Overall temperatures were cool as suggested by a fynbos component with a brief interlude $c a$. 16, 000-14,000 cal year BP when pollen suggests that temperatures increased, before returning to cooler conditions equivalent to the Younger Dryas event. This coincides with a growth hiatus in the large stalagmite between $c a$. 13,300 and 3500 cal year BP (Brook et al. 2015, this issue). Parts of this hiatus are represented by pollen in dung deposits, and excavated floor deposits, indicative of cool conditions up to $c a$. 12,500 cal year BP. Bamford (2015a, b, this issue) also reports slightly more mesic conditions in Late Pleistocene stratum 5 (>12,000BP: LeeThorp and Ecker 2015, this issue) than those prevailing around the cave today. The markedly lower $\delta^{13} \mathrm{C}$ and $\delta^{18} \mathrm{O}$ isotopic values for ostrich eggshell samples from the same stratum 5 are indicative of a large $\mathrm{C}_{3}$ plant component during this phase, interpreted as likely due to higher moisture and lower growth season temperatures (LeeThorp and Ecker 2015, this issue). The phase between $c a$. 12,000 and 6000 cal year BP pollen shows high frequencies of Asteraceae (Scott and Thackeray 2015, this issue), suggesting large proportions of $\mathrm{C}_{3}$ vegetation, consistent with the OES carbon isotopic composition (Lee-Thorp and Ecker 2015, this issue). Based on pollen, isotopes, and microfauna, conditions were generally dry, but there are some indications that moisture availability fluctuated to reach subhumid conditions, e.g., ca. 11,000 cal year BP.

Data on macromammals (Thackeray 1983, 1984, 2015, this issue) and previously published data on micromammals (Avery 1981, 1995) from the Holocene layers at the cave have been interpreted as indicating generally moister conditions in the Early Holocene from $c a$. 7500 to 5100 year BP. This partly overlaps with the time range of moist conditions prevailing in the mid-Holocene from $c a$. 6100 to 5300 year BP as proposed by Lee-Thorp and Ecker (2015, this issue). Thereafter, there was a shift to more arid conditions. Likewise, the pollen data suggest a change in the mid-Holocene from moist grassy conditions $c a$. 5500 year BP, that consequently became slightly drier to support veld similar to that in the cave's environs today (Scott and Thackeray 2015, this issue). This change has tentatively been attributed to reduced winter rainfall and a concomitant increase in summer precipitation (Lee-Thorp and Ecker 2015, this issue).

Isotope data show that the trend towards aridification culminated at about 2000 years, which is consistent with pollen data, indicating a slightly drier grassy vegetation at this time (Scott and Thackeray 2015, this issue). An increase in grazers (as reflected in higher numbers of springbok, Antidorcas marsupialis), in parallel, reflects the expansion of grassland environments (Thackeray 2015, this issue). Further evidence for the "2-3 ka dry period" was found in both the tufa and stalagmite, highlighting that this event may have impacted large parts of the summer rainfall zone of southern Africa (Brook et al. 2015, this issue). After this, conditions fluctuated with several dry intervals at 0-80, 250-400, 550-750, 1200$1500,2100-2250$ cal year BP, interspersed with moist intervals at 80-250, 400-550, $750-1200,1500-2100,2250-2500$ cal year BP. Pollen data derived from the 
stalagmite indicate similar shifts though with less chronological resolution: dry and cool conditions from $c a$. 1540 to 740 cal year BP followed by warmer and moister ones from $c a$. 740 cal BP to today (Brook et al. 2015, this issue).

\section{Early Pleistocene}

In their paper, Fernandez-Jalvo and Avery describe and discuss the taphonomy of the micromammalian remains from the Oldowan/ESA layers, strata 12 and 11, and report that most of the damage is consistent with that resulting from a raptor, probably the barn owl (Tyto alba). They also relate that at least two concentrations of bones indicative of roosts could be identified, a finding which is independently corroborated by the GIS analysis undertaken by Birkenfeld et al. (2015, this issue). Fernandez-Jalvo and Avery (2015, this issue) also suggest that the high frequencies of Gerbillinae and Chrysochloridae in stratum 12 may reflect a relatively drier and more open environment compared to the overlying stratum 11 with higher frequencies of Soricidae, characteristic of moister and cooler conditions.

The Oldowan/ESA strata yielded only a few macrobotanical remains, and so do not offer clear insights of the past vegetation cover (Bamford 2015b, this issue). However, their very presence implies that with an excavation protocol aimed at retrieving such delicate remains (slow and very careful excavation, extensive flotation of sediments, etc.), it may be possible to increase the size of the botanical assemblage substantially.

In contrast, the papers by Rossouw (forthcoming) and Brink et al. (forthcoming) offer extensive information concerning the early Pleistocene palaeoenvironmental record of Wonderwerk Cave. Brink et al. provide data on macromammals only for strata 12 and 11. Bovids characteristic of semiarid conditions make up the bulk of the mammalian faunal assemblage. Despite the small sample sizes, a shift between stratum 12 with more alcelaphines and fewer equids to the opposite proportions in stratum 11 may reflect a change from drier to moister (cooler) conditions, supporting that observed in the micro-mammal assemblages.

Rossouw's forthcoming paper offers a comprehensive record of phytolith assemblages from strata 12 through 9 in Excavation 1. Phytolith composition at the bottom of stratum 12 (dated to $c a$. $1.96 \mathrm{Ma}$ ) correlates with a warm Savanna to Nama-Karoo $\mathrm{C}_{4}$ grassland. This develops into a drier and cooler environment by the top of stratum 12 (dated to $c a .1 .78 \mathrm{Ma}$ ) and continues through to the base of stratum 10 (dated to $c a$. $1.07 \mathrm{Ma}$ ). Based on modern morphotype ecology, this drier and cooler environment would be analogous to a Succulent Karoo community and characterized by $\mathrm{C}_{3}$ subfamilies. The succulent Karoo biome presently lies more than $1000 \mathrm{~km}$ from the cave on the Atlantic coast (Fig. 2). Its shift eastwards to the environs of Wonderwerk Cave would have been facilitated by moister and cooler conditions, possibly resulting from the encroachment of the winter rainfall regime. Further evidence for moist climatic conditions in the region at this time may be the presence of a shallow body of water dating to $c a$. 1.2-1.0 Ma, at Mamatwan located ca. $80 \mathrm{~km}$ north of Wonderwerk Cave (Fig. 1; Matmon et al. 2015). By 1.0 Ma, this body of water had dried up. According to the phytolith record, in mid-stratum 10 (dated to $c a$. 1.0 Ma), extreme fluctuations are evident from cooler to warmer conditions, with a general shift back to a warm Savanna to Nama-Karoo $\mathrm{C}_{4}$ 
grassland by stratum 9. Stable isotope ratios measured on fragments of OES from the same Oldowan/ESA strata chart a similar palaeoenvironmental shift as that recorded by the phytoliths, including fluctuating vegetation signals in stratum 10 (Ecker et al. 2015).

\section{Conclusions}

The papers in the issue represent a step forward in making the results of scientific research at Wonderwerk Cave broadly available. They highlight new finds and insights regarding chronology, material culture, cave occupation history, and palaeoenvironmental and palaeoclimatic conditions at the site and in its surrounds that have far-reaching implications for our understanding of the prehistory of the arid interior of southern Africa as a whole.

Research continues on the wealth of evidence recovered from previous excavations at the site, and a new phase of excavation has now begun aimed at improving recovery of finds and their in situ documentation. The scientific research is integrated with ongoing efforts led by the McGregor Museum and aided by the South African Heritage Resources Agency to protect this spectacular site and make it accessible to the general public. The studies presented here make the importance of Wonderwerk Cave apparent and also leave us well aware that in this context we have truly only scraped the surface.

Acknowledgments We would like to extend our warm thanks to: all members of the Wonderwerk Cave team for their enthusiastic and dedicated support of the project; Colin Fortune (ex-Director), Leon Jacobsen (ex-Vice-Director), Sunet Swanepoel (current Director), and Dr. David Morris (Head of the Archaeology Department) of the McGregor Museum for their support of all aspects of our research project; students from University of Toronto, Simon Fraser University, and other academic institutions who have assisted in field work over the years; Neels Lehule, Iris Khabae, and Johhny Esau, the past and present custodians at the cave, for their help during field seasons. We are grateful to Heinz Rüther and the team from the Zamani Project who, along with Steven James Walker, have provided support for mapping in the cave and the surrounding area, to Jacqueline Studer for translating most of the special issue's abstracts into French, and to Louis Scott, George Brook, and Julia Lee-Thorp for comments on an earlier draft of parts of this manuscript. We would like to acknowledge the invaluable contribution of our friend and colleague the late Hagai Ron, who undertook the paleomagnetic analysis of Wonderwerk Cave, and to whom this special issue is dedicated. Fieldwork at the site is carried out under permit issued by the South African Heritage Resources Agency (SAHRA) and analysis of the archaeological assemblages under the terms of a signed agreement between MC and the McGregor Museum. The current research program builds on the earlier work of Peter Beaumont at the site. Research at Wonderwerk Cave has been funded over the years by grants to MC from the Canadian Social Sciences and Humanities Research Council, Wenner-Gren Foundation and the Halbert Academic Exchange Fund, University of Toronto. We are particularly grateful to Adria LaViolette for the opportunity to publish this issue and for the editorial guidance she has provided.

\section{References}

Avery, D. M. (1981). Holocene micromammalian faunas from the Northern Cape, South Africa. South African Journal of Science, 77, 265-273.

Avery, D. M. (1995). Southern savannas and Pleistocene hominid adaptations: The micromammalian perspective. In E. S. Vrba, G. H. Denton, T. C. Partridge, \& L. H. Burckle (Eds.), Paleoclimate and evolution with emphasis on human origins (pp. 459-47). New Haven: Yale University Press.

Avery, D. M. (2007). Pleistocene micromammals from Wonderwerk Cave, South Africa: Practical issues. Journal of Archaeological Science, 34, 613-625. 
Backhouse, J. (1844). A narrative of a visit to the Mauritius and South Africa. London: Hamilton, Adams and Co.

Bamford, M. (2015a). Charcoal from pre-Holocene stratum 5, Wonderwerk Cave, South Africa. Changing climates, ecosystems and environments within arid Southern Africa and adjoining regions. Palaeoecology of Africa, 33, 153-174. doi:10.1201/b19410-10

Bamford, M. (2015b). Macrobotanical remains from Wonderwerk Cave (Excavation 1), Oldowan to Late Pleistocene (2 Ma to 14 ka BP), South Africa. African Archaeological Review, 32(4). doi:10.1007/ s10437-015-9200-0.

Beaumont, P. B. (1982). Aspects of the Northern Cape Pleistocene project. In J. A. Coetzee \& E. M. van Zinderen Bakker (Eds.), Palaeoecology of Africa and the surrounding islands (Vol. 15, pp. 41-44). Cape Town: A.A. Balkema.

Beaumont, P. B. (1990). Wonderwerk Cave. In P. Beaumont \& D. Morris (Eds.), Guide to archaeological sites in the Northern Cape (pp. 101-134). Kimberly: McGregor Museum.

Beaumont, P. B. (2004). Wonderwerk Cave. In P. Beaumont \& D. Morris (Eds.), Archaeology in the Northern Cape: Some key sites (pp. 31-36). Kimberly: McGregor Museum.

Beaumont, P. B. (2011). The edge: More on fire-making by about 1.7 million years ago at Wonderwerk Cave in South Africa. Current Anthropology, 52(4), 585-595.

Beaumont, P. B., \& Vogel, J. C. (1989). Patterns in the age and context of rock art in the Northern Cape. South African Archaeological Bulletin, 44, 73-81.

Beaumont, P. B., \& Vogel, J. C. (2006). On a timescale for the past million years of human history in central South Africa. South African Journal of Science, 102, 217-228.

Berna, F., Goldberg, P., Horwitz, L. K., Brink, J., Holt, S., Bamford, M., \& Chazan, M. (2012). Microstratigraphic evidence of in situ fire in the Acheulean strata of Wonderwerk Cave, Northern Cape Province, South Africa. Proceedings of the National Academy of Science, 9(20), E1215-E1220.

Binneman, J., \& Beaumont, P. B. (1992). Use-wear analysis of two Acheulean handaxes from Wonderwerk Cave, Northern Cape. South African Field Archaeology, 1, 92-97.

Birkenfeld, M., Avery, M.D., \& Horwitz, L.K. (2015). GIS virtual reconstructions of the temporal and spatial relations of fossil deposits at Wonderwerk Cave (South Africa). African Archaeological Review, 32(4). doi:10.1007/s10437-015-9209-4.

Bradfield, J., Thackeray, J. F., \& Morris, D. (2014). An experimental investigation into the origin of incised lines on a 4000-year-old engraving from Wonderwerk Cave, Northern Cape Province. South African Archaeological Bulletin, 69(199), 72-79.

Breuil, H. E. P. (1945). On the presence of quartzites mechanically broken (sometimes simulating human workmanship in the Dwyka Tillites) and their derivation in the older gravels of the Vaal. South African Journal of Science, 40, 285-399.

Brink, J., Holt, S., \& Horwitz L.K. (2015). The Oldowan and early Acheulean mammalian fauna of Wonderwerk Cave (Northern Cape Province, South Africa). African Archaeological Review, forthcoming.

Brook, G. A., Scott, L., Railsback, B., \& Goddard, E. A. (2010). A 35 ka pollen and isotope record of environmental change along the southern margin of the Kalahari from a stalagmite in Wonderwerk Cave, South Africa. Journal of Arid Environments, 74(5), 870-884.

Brook, G.A., Railsback, B., Scott, L., Riavo, N., Voarintsoa, G., \& Liang, F. (2015). Late Holocene stalagmite and tufa climate records for Wonderwerk Cave: Relationships between archaeology and climate in southern Africa. African Archaeological Review, 32(4). doi:10.1007/s10437-015-9210-y.

Buttner, E.E. (1937). African cave dwellers. Daily Dispatch, East London (newspaper). July 17, 1937.

Butzer, K. W. (1984a). Archaeology and Quaternary environment in the interior of southern Africa. In R. G. Klein (Ed.), Southern African prehistory and paleoenvironments (pp. 1-64). Rotterdam: Balkema.

Butzer, K. W. (1984b). Late Quaternary environments in South Africa. In J. C. Vogel (Ed.), Late Cenozoic palaeoclimates of the Southern Hemisphere (pp. 235-264). Rotterdam: Balkema.

Butzer, K. W., Stuckenrath, R., Bruzewicz, A. J., \& Helgren, D. M. (1978). Late Cenozoic paleoclimates of the Ghaap Escarpment, Kalahari margin, South Africa. Quaternary Research, 10, 310-339.

Butzer, K.W., Stuckenrath, R., \& Vogel J.C. (1979). The geo-archaeological sequence of Wonderwerk Cave, South Africa. Abstract of paper presented at the Society of Africanist Archaeologists meeting, Calgary.

Camp, C. L. (1948). University of California African Expedition southern section. Science, 10, 550-552.

Chazan, M. (2015a). The Fauresmith and archaeological systematics. Palaeoecology of Africa, vol. 33 (Studies in Honor of Louis Scott). CRC Press.

Chazan, M. (2015b). Technological trends in the Acheulean of Wonderwerk Cave, South Africa. African Archaeological Review 32(4). doi:10.1007/s10437-015-9205-8.

Chazan, M., \& Horwitz, L. K. (2009). Milestones in the development of symbolic behaviour at Wonderwerk Cave, South Africa. World Archaeology, 41(4), 521-539. 
Chazan, M., \& Horwitz, L.K. (2015). An overview of recent research at Wonderwerk Cave, South Africa. In I. Thiaw \& H. Bocoum (Eds.), Preserving African cultural heritage (pp. 253-261). Proceedings of the 13th Congress of the Panafrican Archaeological Association for Prehistory and Related Studies - PAA, and of the 20th Meeting of the Society of Africanist Archaeologists - SAfA, Dakar. Mémoires de l'IFAN - C. A. DIOP, $n^{\circ} 93$.

Chazan, M., Ron, H., Matmon, A., Porat, N., Goldberg, P., Yates, R., Avery, M., Sumner, A., \& Horwitz, L. K. (2008). First radiometric dates for the Earlier Stone Age sequence in Wonderwerk Cave, South Africa. Journal of Human Evolution, 55, 1-11.

Chazan, M., Avery, M. D., Bamford, M. K., Berna, F., Brink, J., Fernandez-Jalva, Y., Goldberg, P., Holt, S., Matmon, A., Porat, N., Rossouw, L., Scott, L., \& Horwitz, L. K. (2012). The Oldowan horizon in Wonderwerk Cave (South Africa): Archaeological, geological, paleontological and paleoclimatic evidence. Journal of Human Evolution, 63, 859-866.

Dart, R. A. (1925). Australopithecus africanus: The man-ape of South Africa. Nature, 115, 195-199.

De Ruiter, D. J. (2003). Revised faunal lists for members 1-3 of Swartkrans, South Africa. Annals of the Transvaal Museum, 40, 29-41.

Ecker, M., Botha-Brink, J., Lee-Thorp, J.A., Piuz, A., \& Horwitz, L.K. (2015). Ostrich eggshell as a source of palaeoenvironmental information for the arid interior of South Africa. Changing climates, ecosystems and environments within arid Southern Africa and adjoining regions. Palaeoecology of Africa vol. 33 Studies in Honor of Louis Scott. CRC Press.

Fernández-Jalvo Y., \& Avery D.M. (2015). Pleistocene micromammals and their predators at Wonderwerk Cave, South Africa. African Archaeological Review, 32(4).

Goldberg P., Berna F., \& Chazan M. (2015). Deposition and diagenesis in the Earlier Stone Age of Wonderwerk Cave, Excavation 1, South Africa. African Archaeological Review, 32(4). doi:10.1007/ s10437-015-9192-9.

Goodwin, A. J. H. (1928). The archaeology of the Vaal River gravels. Transactions of the Royal Society of South Africa, 16, 77-102.

Goodwin, A. J. H., \& van Riet Lowe, C. (1929). The Stone Age Cultures of South Africa. Annals of the South African Museum, 27, 1-270.

Granger, D. E., Gibbon, R. J., Kuman, K., Clarke, R. J., Bruxelle, L., \& Caffee, M. C. (2015). New cosmogenic burial ages for Sterkfontein Member 2 Australopithecus and Member 5 Oldowan. Nature, $522,85-88$.

Humphreys, A. J. B., \& Thackeray, A. I. (1983). Ghaap and Gariep. Cape Town: South African Archaeological Society.

Johnson, J. P., \& Young, R. B. (1906). The relation of ancient deposits of the Vaal River to the Palaeolithic period of South Africa. Transactions of the Geological Society of South Africa, 9, 53-56.

Kunneriath, M., \& Gaillard, C. (2010). Techno-typological analysis of lithic collections from Sheppard Island and Pniel, Vaal River Valley, South Africa. Annali dell'Università di Ferrara, Museologia Scientifica e Naturalistica, 6, 111-116.

Lee-Thorp, J.A., \& Ecker, M. (2015). Holocene environmental change at Wonderwerk Cave, South Africa: Insights from stable light isotopes in ostrich egg shell. African Archaeological Review, 32(4). doi:10.1007/ s10437-015-9202-y.

Malan, B. D., \& Cooke, H. B. S. (1941). A preliminary account of the Wonderwerk Cave, Kuruman. South African Journal of Science, 37, 300-312.

Malan, B. D., \& Wells, L. H. (1943). A further report on the Wonderwerk Cave, Kuruman. South African Journal of Science, 40, 258-270.

Matmon, A., Ron, H., Chazan, M., Porat, N., \& Horwitz, L. K. (2012). Reconstructing the history of sediment deposition in caves: A case study from Wonderwerk Cave. Geological Society of America Bulletin, 124, $611-625$.

Matmon A., Hidy A.J., Vainer S., Crouvi O., Fink D., Erel Y., ASTER Team, Horwitz L.K., \& Chazan M. (2015). New chronology for the southern Kalahari Group sediments with implications for sediment-cycle dynamics and early hominin occupation. Quaternary Research.

Methuen, H. H. (1846). Life in the wilderness; or, wanderings in South Africa. London: R. Bentley.

Mitchell, P. J. (1998). The South African Stone Age in the collections of the British Museum: Content, history and significance. South African Archaeological Bulletin, 53(167), 26-36.

Morris, D. (2015). The parietal art of Wonderwerk Cave - a preliminary comment. African Archaeological Review, forthcoming.

Mucina, L., \& Rutherford, M. C. (2006). The vegetation of South Africa, Lesotho and Swaziland. Strelitzia (Vol. 19). Pretoria: South African National Biodiversity Institute. 
Ogola, C. A. (2009). The Sterkfontein western breccias: Stratigraphy, fauna and artefacts PhD dissertation, Faculty of Science, University of the Witwatersrand, Johannesburg.

Peabody, F. E. (1954). Travertines and cave deposits of the Kaap escarpment of South Africa, and the type locality of Australopithecus africanus Dart. Bulletin of the Geological Society of America, 65(7), 671-706.

Péringuey, L. (1911). The Stone Ages of South Africa as represented in the collections of the South African Museum. Annals of the South African Museum, 8, 1-218.

Pickering, R. (2015). U-Pb dating small buried stalagmites from Wonderwerk Cave, South Africa: a new chronometer for earlier stone age cave deposits. African Archaeological Review, 32(4). doi:10.1007/ s10437-015-9203-x.

Power, J. H. (1955). Power's site. South African Archaeological Bulletin, 10(39), 96-101.

Reed, K. E. (1996). The paleoecology of Makapansgat and other African Plio-Pleistocene hominid localities. Ph.D. Dissertation, State University of New York at Stony Brook.

Rossouw, L. (2015). An early Pleistocene phytolith record from Wonderwerk Cave, Northern Cape, South Africa. African Archaeological Review, forthcoming.

Rüther, H., Chazan, M., Schroeder, R., Neeser, R., Held, C., Walker, S. J., Matmon, A., \& Horwitz, L. K. (2009). Laser scanning for conservation and research of African cultural heritage sites: The case study of Wonderwerk Cave, South Africa. Journal of Archaeological Science, 36, 1847-1856.

Rutherford, M. C., Micina, L., \& Powrie, L. W. (2006). Biomes and bioregions of southern Africa. Strelitzia, $19,32-51$.

Sampson, C. G. (1974). The Stone Age archaeology of Southern Africa. New York: Academic Press.

Scott, L., Steenkamp, M., \& Beaumont, P. B. (1995). Palaeoenvironmental conditions in South Africa at the Pleistocene-Holocene transition. Quaternary Science Reviews, 14 (9), 937-947.

Scott, L., \& Thackeray, J.F. (2015). Palynology of Holocene deposits in Excavation 1 at Wonderwerk Cave, Northern Cape (South Africa). African Archaeological Review, 32(4). doi:10.1007/s10437-015-9204-9.

South African Rain Atlas, online resource http://134.76.173.220/rainfall/index.html

Thackeray J.F. (1983). Man, animals and extinctions: The analysis of Holocene faunal remains from Wonderwerk Cave, South Africa. PhD thesis, Yale University.

Thackeray, J. F. (1984). Climatic change and mammalian fauna from Holocene deposits, Wonderwerk Cave. In J. C. Vogel (Ed.), Late Cainozoic palaeoclimates of the Southern Hemisphere (pp. 371-374). Rotterdam: Balkema.

Thackeray, J. F. (1988). Zebras from Wonderwerk Cave, northern Cape Province: Attempts to distinguish Equus burchelli and E. quagga. South African Journal of Science, 84, 99-101.

Thackeray, J. F. (2005). The wounded roan: A contribution to the relation of hunting and trance in southern African rock art. Antiquity, 79, 5-18.

Thackeray, J. F. (2015). Faunal remains from Holocene deposits, Excavation 1, Wonderwerk Cave, South Africa. African Archaeological Review, 32(4). doi:10.1007/s10437-015-9201-z.

Thackeray, J. F., \& Brink, J. S. (2004). Damaliscus niro horns from Wonderwerk Cave and other Pleistocene sites: Morphological and chronological considerations. Palaeontologica Africana, 40, 89-93.

Thackeray, J. F., \& Lee-Thorp, J. A. (1992). Isotopic analysis of equid teeth from Wonderwerk Cave, northern Cape Province, South Africa. Palaeogeography, Palaeoclimatology, Palaeoecology, 99(1-2), 141-150.

Thackeray, A. I., Thackeray, J. F., Beaumont, P. B., \& Vogel, J. C. (1981). Dated rock engravings from Wonderwerk Cave, South Africa. Science, 214, 64-67.

Tobias, P. V. (1992). New researches at Sterkfontein and Taung with a note on Piltdown and its relevance to the history of palaeo-anthropology. Transactions of the Royal Society of South Africa, 48(1), 1-14.

van Zinderen Bakker, E. M. (1982). Pollen analytical studies of the Wonderwerk Cave, South Africa. Pollen et Spores, 24(2), 235-250.

Watson, V. (2004). Composition of the Swartkrans bone accumulations in terms of skeletal parts and animals represented. In C. K. Brain (Ed.), Swartkrans: A cave's chronicle of early man (2nd. Ed.) (pp. 35-73). Pretoria: Transvaal Museum Monograph, 8.

Watts, I., Wilkins, J., \& Chazan M. (2015). Early evidence for brilliant ritualized display: Specularite use in the Northern Cape (South Africa) between $\sim 500 \mathrm{ka}$ and $\sim 300 \mathrm{ka}$. Current Anthropology.

Wells, L. H. (1964). The Vaal River 'younger gravels' faunal assemblage, a revised list. South African Journal of Science, 60, 91-93. 